\title{
The possible role of Myosin light chain in myoblast proliferation
}

\author{
SU-ZHEN ZHANG ${ }^{1, A}$, YONG XU2, A, HUI-QI XIE ${ }^{3,}$, XIU-QUN LI ${ }^{3}$, YU-QUAN WEI ${ }^{2}$, \\ and ZHI-MING YANG ${ }^{3}$ *
}

\begin{abstract}
${ }^{1}$ Division of Stem Cell and Tissue Engineering, State Key Laboratory of Biotherapy, West China Hospital, West China Medical School and School of Life Science, Sichuan University, Chengdu, 610041, P. R. China ${ }^{2}$ State Key Laboratory of Biotherapy and Cancer Center, West China Hospital, West China Medical School and School of Life Science, Sichuan University, Chengdu, 610041, P. R. China

${ }^{3}$ Division of Stem Cell and Tissue Engineering, State Key Laboratory of Biotherapy, West China Hospital, West China Medical School, Sichuan University, Chengdu, 610041, P. R. China

A These authors contributed equally to this work.
\end{abstract}

\begin{abstract}
Skeletal muscles have the potential to regenerate by activation of quiescent satellite cells, however, the molecular signature that governs satellite cells during muscle regeneration is not well defined. Myosin light chains (Myls) are sarcomere-related proteins as traditional regulator of muscle contraction. In this report, we studied the possible role of Myl in the proliferation of skeletal muscle-derived myoblasts. Compared to diaphragm-derived myoblasts, the extraocular muscle-derived myoblasts with lower levels of Myl proliferated faster, maintained a longer proliferation phase, and formed more final myotubes. It was found that blockading Myl with anti-Myl antibody or knockdown of Myl1 by siRNA targeted against Myl1 could enhance the myoblast proliferation and delay the differentiation of myoblasts. Our results suggested that Myl, likely Myl1, can negatively affect myoblast proliferation by facilitating myoblast withdrawal from cell cycle and differentiation.
\end{abstract}

Key terms: Myosin light chain, Proliferation, Myoblast, Extraocular muscle

\section{INTRODUCTION}

Skeletal muscle possesses a highly regenerative potential after severe injury or a myopathic disease. However, in severity of response to myopathic disease, skeletal muscle groups differ among themselves. For example, in Duchenne Muscular Dystrophy (DMD), which is an X-linked recessive muscle-wasting disorder, extraocular muscles $(\mathrm{EOM})$ remain clinically spared, despite severe damage seen in other skeletal muscles, especially in the diaphragm (Kaminski et al., 1992; Khurana et al., 1995; Porter et al., 2004). The exact mechanisms remain unclear so far. Although compared to other skeletal muscles, the EOMs are inherently different in their molecular makeup and physiological properties, the efficient and continuous regeneration and/or myogenesis in EOMs has been suggested as an important mechanism responsible for their sparing in DMD (Fischer et al., 2002; McLoon et al., 2002; Fischer et al., 2005). Consequently, increasing the regenerative capacity of skeletal muscle could influence the evolution of congenital myopathies.

Muscle regeneration primarily relies on the activation of a specific cell population called satellite cells, which are normally quiescent and situated between the basal

\footnotetext{
* To whom correspondence should be addressed (Division of Stem Cell and Tissue Engineering, State Key Laboratory of Biotherapy, West China Hospital, West China Medical School, Sichuan University, Gaopeng Street, Keyuan Road 4, Chengdu, 610041, Sichuan, P. R. China. Tel.: (+86)28-85164088. Fax: (+86)28-85164088. E-mail: zywoffa@yahoo.com, orthop@public.cd.sc.cn
} 
lamina and the plasma membrane of adjacent myofiber (Dhawan et al., 2005; Shi Dhawan et al., 2005). Upon activation, satellite cells re-enter the cell cycle and proliferate. Ultimately, the progeny cells myoblasts withdraw from the cell cycle and fuse to form multinucleated myotubes (Schultz et al., 1985; Conboy et al., 2003). The molecular signature that governs satellite cells during muscle regeneration is complex and incompletely understood. And the regulatory cascades await further study.

In our comparative proteomics study (data not shown), we identified myosin light chains (Myls) as the differentially expressed proteins between EOM and the diaphragm. Compared to the diaphragm, EOM expressed Myl1, Myl2 and Myl3 at lower levels. Myls are the principal components in myofibrils and associated with myosin heavy chain heads. According to the conditions dissociated from the myosin heavy chains, Myls are divided into two classes (Barton et al., 1985; Hailstones et al., 1990). One is called the regulatory (or phosphorylatable) light chain (i.e. Myl2) and the other is the alkali light chain (i.e. Myl1, Myl3 and Myl4). Each class has several isoforms associated with different muscle types. For alkali Myls, Myl1, Myl3 and Myl4 are the fast-muscle isoform, slow-twitch / ventricular muscle isoform and embryonic / atrial muscle isoform, respectively. In vertebrate striated muscle, the acto-myosin interaction during muscle contraction is mainly regulated through the troponin/tropomyosin system, and Myls are considered to have only a minor modulatory effect on muscle contraction (Rushforth et al., 1998; Timson et al., 2003; Andruchov et al., 2006). Thus, the precise physiological function of Myls in striated muscle is not as yet clear. Earlier studies showed that ventricular Myl2 has a role in the regulation of cardiogenic development (Chen et al., 1998), which was supported by subsequent studies (Ghatpande et al., 2001). Jiang et al. (2002) found that precocious expression of MLC1f/3f (i.e. Myl1) results in developmentally delayed mouse embryos and mesoderm ablation, and suggested that the precocious presence of muscle-specific contractile protein isoforms may disrupt cell proliferation. These findings, combined with our comparative proteomics study (data not shown), led us speculate that Myl may be involved in myogenesis or muscle regeneration through its function in myogenic cells. Our study was undertaken to examine the problem by using myoblasts derived from EOM and diaphragm muscles.

\section{MATERIALS AND METHODS}

\section{Cell culture}

Primary myoblasts were derived from EOM and diaphragm muscles of 3 -wk-old C57BL/6 mice using a modified preplate technique (Qu-Petersen et al., 2002). Mice were euthanized by cervical dislocation, and EOM and diaphragm muscles were isolated, digested with collagnase-type I and dispase, and then centrifuged. The cells were first plated on 6-well plates for $2 \mathrm{~h}$ (preplate 1, pp 1) in growth medium (DMEM plus 20\% FBS and $100 \mathrm{U} / \mathrm{ml}$ penicillin and $100 \mu \mathrm{g} / \mathrm{ml}$ streptomycin) at $5 \% \mathrm{CO}_{2}$ and $37^{\circ} \mathrm{C}$. Then, the non-adherent cells were transferred to other wells (pp2). After $48 \mathrm{~h}$, the floating cells in pp2 were collected and plated on new wells (pp3). After $48 \mathrm{~h}$, the pp3 cells were obtained. The pp1 and pp2 cells were discarded because they contained non-myogenic cells $(\mathrm{Qu}$ et al., 1998; Qu-Petersen et al., 2002). The pp3 cells were expanded and passaged, and only passage 1 cells were used in the following experiments. The purity and myogenic potential of the pp3 cells were evaluated by desmin staining. Animals were used in accordance with principles in the care and use of animals of the Sichuan University.

\section{Immunocytochemistry}

The myoblasts from EOM and diaphragm fixed with $4 \%$ paraformaldehyde on coverslips were permeabilized with $0.1 \%$ Triton X-100 in PBS at room temperature, then incubated with desmin antibody (1:100 monoclonal mouse anti-desmin, Sigma) for 1 h. After three rinses in PBS, the cultures were incubated with FITC-labeled secondary 
antibodies and examined with a fluorescent microscope (Nikon ECLIPSE 90i) equipped with a digital camera (Nikon DXM 1200F). The nuclei were stained with DAPI.

\section{Myoblast proliferation assay}

Myoblasts from EOM and diaphragm were seeded at 4160 cells $/ \mathrm{cm}^{2}$ in 96-well plates, and cell number was determined using the methylene blue assay (Oliver et al., 1989). Myoblasts were also seeded on the coverslips at 7860 cells $/ \mathrm{cm}^{2}$ to monitor cell proliferation, and cells in $\mathrm{S}$ phase were pulsed with $0.1 \mathrm{mM}$ BrdU for $15 \mathrm{~min}$ at $1 \mathrm{~d}$, $3 \mathrm{~d}$, and $5 \mathrm{~d}$, then fixed to detect BrdUpositive cells by immunocytochemistry as previously described (Knudsen et al., 1998).

To demonstrate the effect of Myl on myoblast proliferation, diaphragm-derived myoblasts were seeded at 4160 cells $/ \mathrm{cm}^{2}$ in 96-well plates, and exposed to anti-Myl monoclonal antibody (Clone MY-21, Sigma) in increasing concentrations from 1 to $1000 \mathrm{ng} / \mathrm{ml}$. After $38 \mathrm{~h}$, cell proliferation was assessed as described above. The proliferation assay showed that the maximum effect of anti-Myl antibody on myoblast growth was seen at $8 \mathrm{ng} / \mathrm{ml}$ when the optical density tended to reach maximum. Therefore, the following proliferation assay on myoblasts from EOM and the diaphragm was performed in parallel with serial concentrations from 1 to $16 \mathrm{ng} / \mathrm{ml}$.

\section{siRNA transfection of myoblasts}

Inhibition of Myl1 expression in myoblasts was achieved by RNA interference. Three individual siRNAs against Mylland nontargeted control siRNA (NcontrolsiRNA) were obtained from Ribobio (Guangzhou, China). The efficient silencing of the Myll gene was assessed by immunoblotting using a primary antibody directed against Myl(Clone MY-21, Sigma). Myl1-siRNA (40 $\mathrm{nM}$ final) or Ncontrol-siRNA (40 $\mathrm{nM}$ final) was transfected into myoblasts using Lipofectamine 2000 according to the manufacturer's instructions (Invitrogen). Lipofectamine 2000 without siRNA was used as the control. 48 hours following transfection, myoblasts were collected and prepared for Western blot analysis with inmunoblotting.

To further test the effect of Myl1 on myoblast proliferation, EOM- and diaphragm-derived myoblasts were seeded at $7860 \mathrm{cells} / \mathrm{cm}^{2}$ in $96-$ well plates and cultured overnight in the growth medium. After being transfected with Myl1-siRNA (40 nM final), the cell number was determined by methylene blue assay at 0,1 , 2 , and $3 \mathrm{~d}$.

\section{$R T-P C R$ analysis}

Total RNA was isolated from myoblasts at $24 \mathrm{~h}$ after seeding using TRIzol reagents (Invitrogen). After synthesis of the first strand cDNA, the following primers were used for specific gene PCR: for Myl1 (product size 148 bp) were 5' TGCCCATGATGCAAGCTATCTC-3' and 5'-ATCTTCTCTCCCAGAGTGGCGA-3'; for Myl2 (product size $258 \mathrm{bp}$ ) were 5'AGAACAGAGACGGCTTCATCG-3' and 5'-TCAGCATCTCCCGGACATAGT-3'; for Myl3 (product size 197 bp) were 5'CCAAGAACAAGGACACTGGCA-3' and 5'-CGCTTCATAGTTGATGCAGCC-3'; for Myl4 (product size $263 \mathrm{bp}$ ) were 5'GCAAACCCAAGCCTGAAGAGA-3' and 5'-GTTGATGCAGCCATTGGCA-3'; and for GAPDH (product size $191 \mathrm{bp}$ ) were 5'AACGACCCCTTCATTGAC-3' and 5'TCCACGACATACTCAGCAC-3', PCR products were resolved on $2 \%$ agarose gels. The band intensity ratio of the specific gene to the internal standard (GAPDH) was used to represent the level of gene expression.

\section{Western blot analysis}

Whole-cell proteins from myoblasts at $24 \mathrm{~h}$ after seeding and myoblasts at $48 \mathrm{~h}$ after Myl1-siRNA treatment were equally resolved on SDS-PAGE in $12 \%$ acrylamide gels, respectively. The proteins were transferred onto a PVDF membrane (Boehringer Mannheim GmbH, Germany) and probed with the Myl monoclonal mouse antibody (Clone MY-21, Sigma; 1:800). Secondary HRP-conjugated anti-mouse IgG 
antibody (1:50000) were used in combination with ECL reaction (Rockford, IL, Pierce). Densitometric analysis was performed using the Quantity One 1-D analysis software (Bio-Rad).

\section{Myotube assay}

Myoblasts from EOM and diaphragm muscles were seeded in 6-well plates at 7860 cells $/ \mathrm{cm}^{2}$ and kept in growth medium; the cells subsequently began to fuse into myotubes at low confluence (Qu-Petersen et al., 2002). The cultures were examined every $2 \mathrm{~h}$ until the emergence of myotubes, and the final number of myotubes was counted from five random microscopic fields and averaged at $144 \mathrm{~h}$ after seeding.

To assess the effect of Myl on myotube formation, diaphragm-derived myoblasts were seeded at 4160 cells $/ \mathrm{cm}^{2}$ in 6-well plates. Anti-Myl antibody was added at a dosage of $8 \mathrm{ng} / \mathrm{ml}$, and the number of myotubes was determined at $16 \mathrm{~h}$ and $144 \mathrm{~h}$ respectively. To further determine the effect of Myl1 on myotube formation, diaphragmderived myoblasts were seeded at 4160 cells/ $\mathrm{cm}^{2}$ in 6-well plates and cultured overnight $(12 \mathrm{~h})$ in the growth media. Myl1-siRNA (40nM final) was then added to the cultures, and the number of myotubes per well was counted at $48 \mathrm{~h}$ after Myl1-siRNA treatment.

\section{Statistical analysis}

Statistical analysis was performed using SPSS14.0. The significance between groups was determined by ANOVA. All results are presented as means $\pm \mathrm{SD}$.

\section{RESULTS}

The expression of Myls in proliferating myoblasts derived from EOM and the diaphragm

Previous works have demonstrated that proliferating primary myoblasts express myoblast markers such as desmin, which is expressed only in myogenic cells (Rando et al, 1994; Qu-Petersen et al., 2002; McCroskery et al., 2003). To characterize the cultures used in this experiment, we immunostained the myoblast cultures with desmin-specific antibodies. Figure 1 showed that over $95 \%$ of primary cells derived from EOM and diaphragm expressed desmin, indicating that the isolation procedure generated highly purified cultures of myogenic cells from both EOM and diaphragm.

EOM and diaphragm display different response to muscular dystrophy. Our comparative proteomics studies (data not shown) have revealed that EOMs had a lower level of Myls (mainly Myl1, Myl2 and Myl3) as compared with diaphragm muscles. To determine whether the myoblasts from EOM and diaphragm have a different expression of Myls, we harvested the EOM- and diaphragm-derived myoblasts at $24 \mathrm{~h}$ after seeding, and the expression of Myls in myoblasts was measured by RT-PCR and Western blot analysis. As seen in Figure $2 \mathrm{~A}$, the expression levels of Myl1 and Myl4 mRNA in EOM-derived myoblasts were both lower than those in diaphragm-derived myoblasts. Neither Myl2 nor Myl3 mRNA was detected in these two myoblasts. Western blot analysis showed that EOM-derived myoblasts expressed Myl proteins at lower level compared with diaphragm-derived myoblasts. These results indicated that Myl expressions in the EOM-derived myoblasts were different from those in the diaphragmderived myoblasts.

\section{EOM-derived myoblasts proliferate faster}

The different regenerative potential of muscle groups may contribute to their heterogeneous response to muscular dysthophy. Thus, we examined whether there is different proliferation potential between EOM-derived myoblasts and diaphragm-derived myoblasts. We plated myoblasts isolated from EOM and diaphragm muscles and determined their proliferation using the methylene blue cell proliferation assay. Compared to the diaphragm-derived myoblasts, the EOMderived myoblasts proliferated faster, which resulted in a significant increase in the number of cells (Fig. 2B). We also 
monitored the myoblast proliferation by pulsing myoblasts in the $\mathrm{S}$ phase of the cell cycle with BrdU at specific time points. Cells labeled with BrdU reflect that they are in a proliferating state. Figure 2C showed that the percentages of BrdUpositive cells in EOM-derived myoblasts were significantly higher than those in diaphragm-derived myoblasts at various time points, suggesting that more EOMderived myoblasts were in proliferating state when compared with the diaphragmderived myoblasts.

\section{Myl blockade or knockdown increases the myoblast proliferation}

Proliferation assays clearly demonstrated that EOM-derived myoblasts with lower levels of Myls proliferated faster than diaphragm-derived myoblasts that expressed Myls at relatively high levels. These findings lead us to speculate that there could be a relationship between Myl and the proliferative capacity of muscle cells. Thus, we tested the function of Myl in myoblast proliferation. For this purpose, an antibody specific for Myl was added to the myoblast cultures in a series of concentrations (from 1 to $1000 \mathrm{ng} / \mathrm{ml}$ ). Because there is a higher level of Myl in diaphragm-derived myoblasts, we thought that it should be more sensitive to antibody. Consequently, we carried out the examination in diaphragm-derived myoblasts first. As shown in Figure 3A, we observed significant increases in cell proliferation at $38 \mathrm{~h}$ after antibody treatment, they displayed dose-dependence on antibodies in a given range. When the concentration reached $8 \mathrm{ng} / \mathrm{ml}$, the effect of the antibody tended to peak. These results
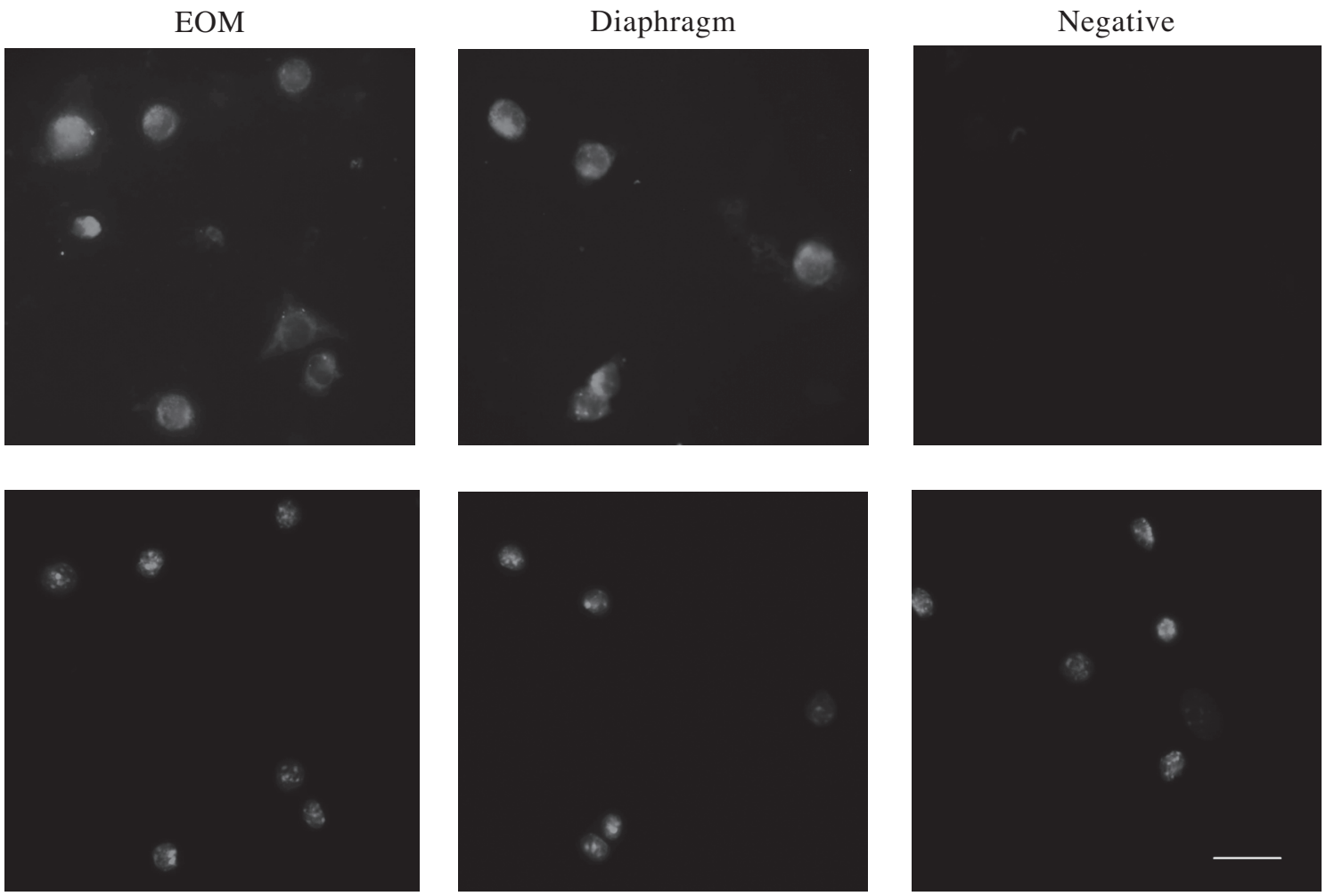

Fig. 1: Expression of desmin in EOM- and diaphragm-derived myoblasts. Primary myoblasts were cultured from the EOM and diaphragm muscles, fixed, and immunostained for desmin. The nuclei stained with DAPI in the corresponding fields were shown; Immunostaining without primary antibody was used as negative control. Greater than $95 \%$ of the primary cultured cells were myogenic. Bar, $10 \mu \mathrm{m}$. 
showed that the anti-Myl antibody exerted a neutralizing role. Based on these results, a series of concentrations, ranging from 1 to $16 \mathrm{ng} / \mathrm{ml}$, were adopted by subsequent experiments. The myoblasts isolated from both EOM and the disphragm were cultured and anti-Myl antibody was added in increasing concentrations. Thirty-eight hours after treatment with the anti-Myl antibody, the proliferation rate of myoblasts from EOM and disphragm were enhanced (Fig. 3B).

\section{A}

Mark EOM Diaphragm EOM Diaphragm
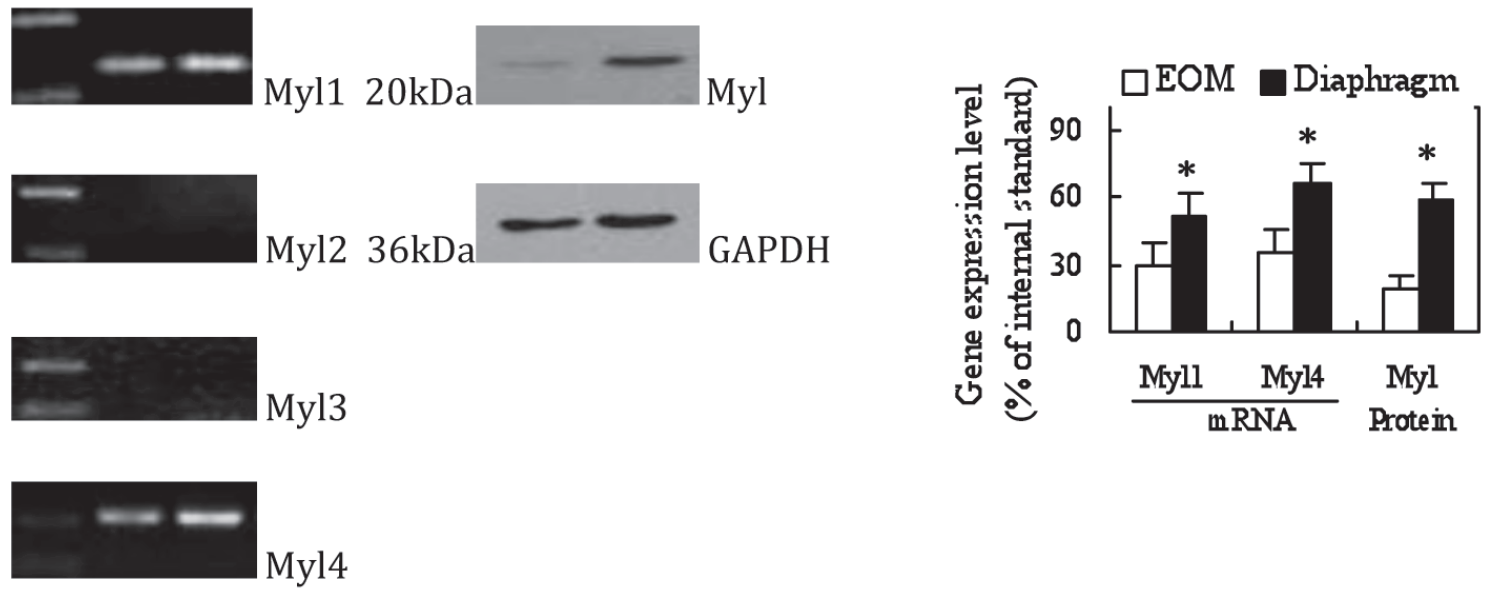

B

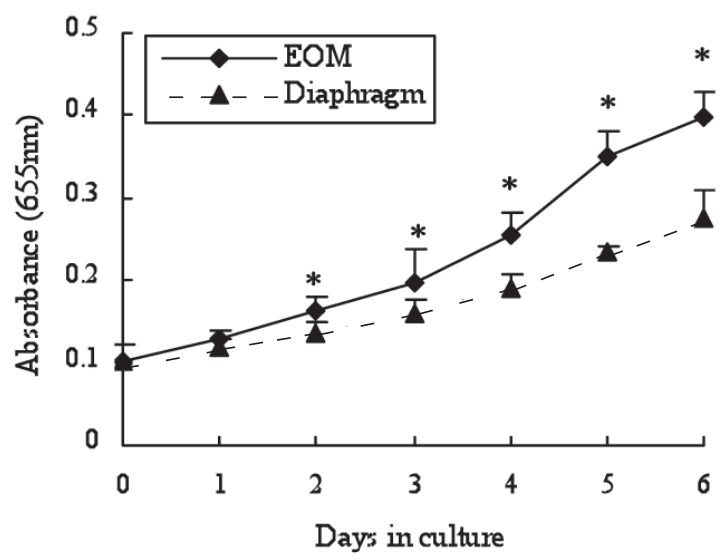

C

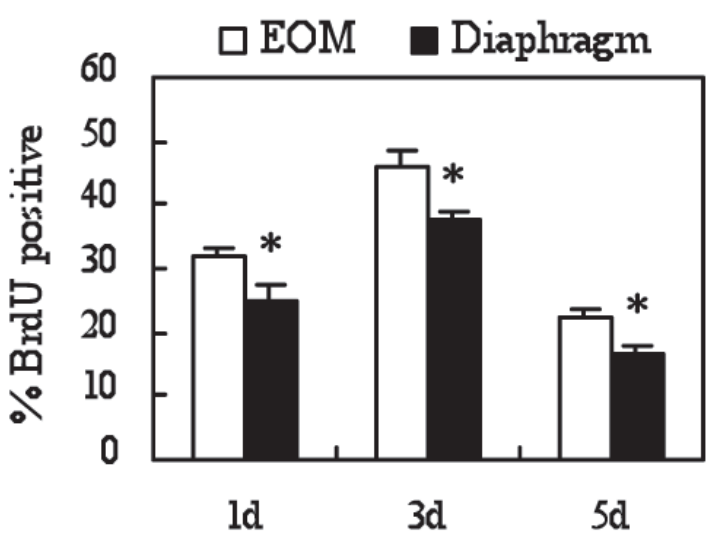

Fig. 2: EOM-derived myoblasts with lower level of Myl proliferate faster. (A) Expression of Myls in myoblasts. Myl1-4 mRNA expressions were analyzed by RT-PCR and Myl protein was analyzed by Western blot. Myl2 and Myl3 amplicons were not detected at the proliferateive myoblasts. The results are expressed as means \pm SD from three independent experiments. ${ }^{*} p<0.05$, vs EOM. (B) Proliferation curves. EOM- and diaphragm-derived myoblasts proliferation rate was determined by the methylene blue assay. Experiments were performed in quadruplicate, and three independent experiments were done. $* \mathrm{P}<0.01$ vs diaphragm. (C) Proliferation assay by BrdU labeling. Myoblasts in $\mathrm{S}$ phase were pulsed with $\mathrm{BrdU}$ for $15 \mathrm{~min}$ at $1 \mathrm{~d}, 3 \mathrm{~d}$, and $5 \mathrm{~d}$, then fixed and immunostained for BrdU. Data are from three independent experiments, with at least 500 cells scored per experiment. $* \mathrm{P}<0.05$ vs EOM. 
We also tested the effect of Myl (mainly Myl1) on myoblast proliferation by using specifically-targeted siRNA to delete the expression of Myl1 in myoblasts. Figure 3C and D showed that the Myl1 expressions in EOM- and disphragm-derived myoblasts were efficiently suppressed by Myl1-siRNA and the proliferation of these cells was significantly enhanced after treatment with Myl1-siRNA. These results indicated that Myl, likely Myl1, may negatively affect myoblast proliferation.
A

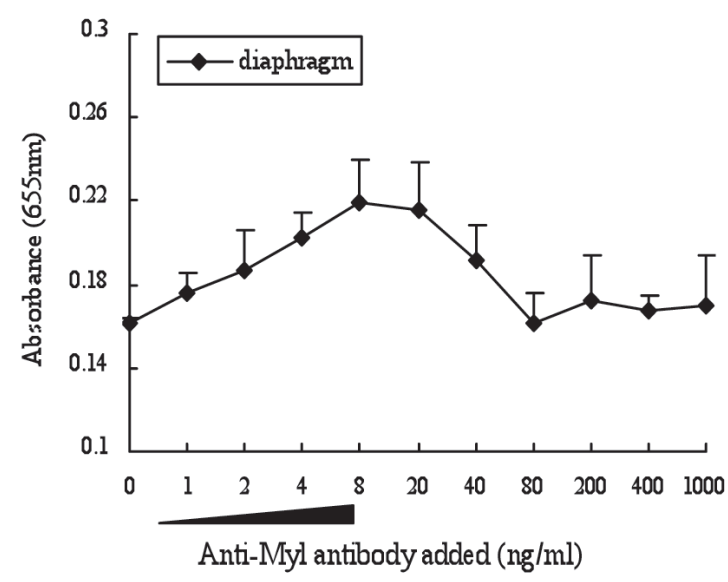

C

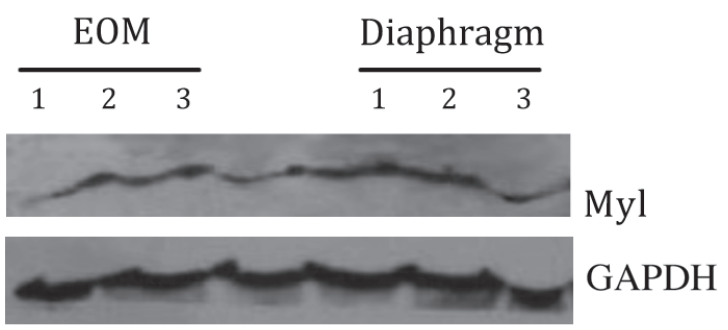

B

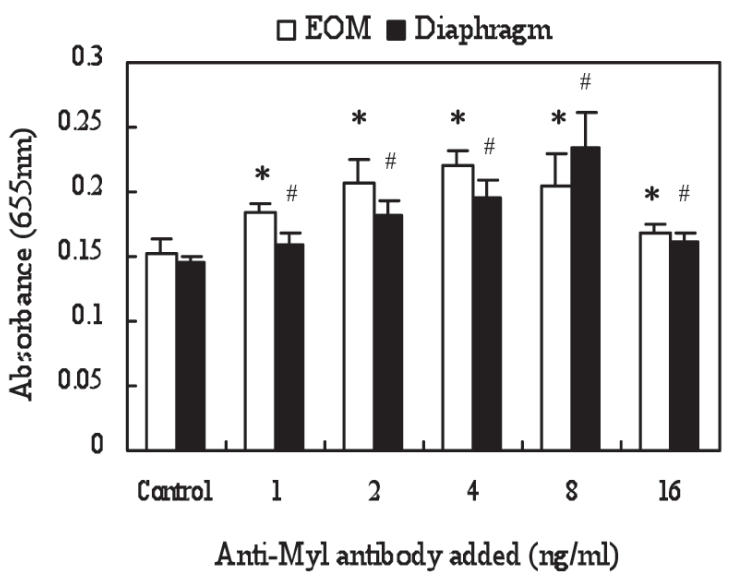

D

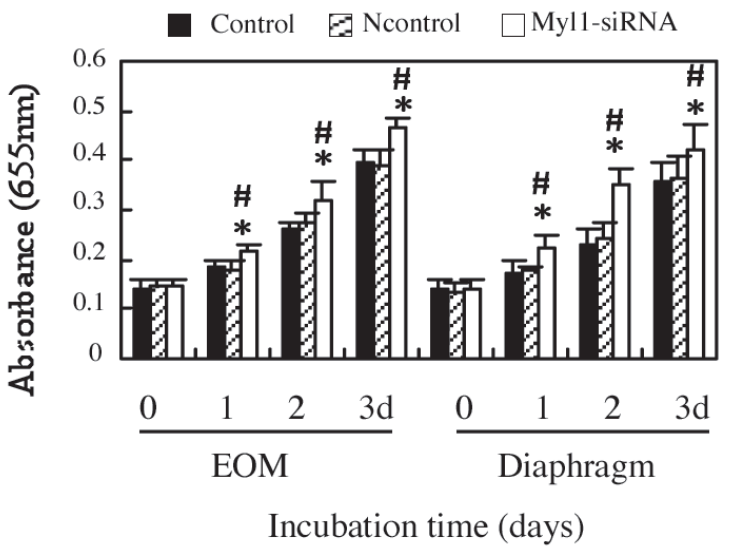

Fig. 3: Increase of myoblast proliferation by Myl blockade and deletion. (A) Diaphragm-derived myoblasts were incubated with anti-Myl antibody in increasing concentrations from 0 to $1000 \mathrm{ng} /$ $\mathrm{ml}$. By $38 \mathrm{~h}$, the proliferative potential of the myoblasts increased in a dose-dependent manner and tended to peak at the concentration of $8 \mathrm{ng} / \mathrm{ml}$. (B) EOM- and diaphragm-derived myoblasts were cultured in the medium containing anti-Myl antibody from 1 to $16 \mathrm{ng} / \mathrm{ml}$ for $38 \mathrm{~h}$, and PBS was used as the control. The assays were performed in quadruplicate and means \pm SD from three independent experiments. ${ }^{*} \mathrm{P}<0.01$ (EOM, as compared with control); ${ }^{\#} \mathrm{P}<0.01$ (diaphragm, as compared with control). (C) Myoblasts from EOM and diaphragm were transfected with Myl1-siRNA (40 nM final) or Ncontrol-siRNA (40 nM final) using Lipofectamine 2000. The vehicle without siRNA was used as the control. After 48h, Myl expressions in myoblasts were detected by Western blot analysis (1: Control; 2: Ncontrol; 3: Myl1-siRNA). (D) EOM- and diaphragm-derived myoblasts were transfected with Myl1-siRNA (40 nM final), then cell counting was made by the methylene blue assay at the indicated time points. The assays were performed in quadruplicate and the data were expressed as mean \pm SD from three independent experiments. ${ }^{*} \mathrm{P}<0.05$, vs Control; ${ }^{\#} \mathrm{p}<0.05$, vs Ncontrol. 
Delayed differentiation potential of myoblasts with lower level of Myl or blockage of $\mathrm{Myl}$

Myogenic differentiation of myoblasts occurs based on withdrawal of actively growing myoblasts from the cell cycle into the G0 phase. Myoblasts cultured in growth medium could differentiate and fuse into myotubes at low confluence $(\mathrm{Qu}-\mathrm{Petersen}$ et al., 2002). Thus, we performed myotube experiments to investigate the differentiation potential of myoblasts from EOM and diaphragm. Diaphragm-derived myoblasts began to yield myotubes at $16 \mathrm{~h}$ after seeding. But myotubes from EOM-derived myoblasts did not emerge until $40 \mathrm{~h}$ after seeding (Fig. 4). At 144h, however, the number of myotubes derived from EOM was significantly higher than that of myotubes from diaphragm myoblasts.

To determine whether Myl affects the differentiation potential of myoblasts, we treated myoblast cultures with anti-Myl antibody and Myl1-siRNA and observed myotube formation. Because diaphragm myotubes formed faster, only diaphragmderived myoblasts were used in the experiment. As shown in Figure 5A, after anti-Myl antibody treatment, the number of myotubes at $16 \mathrm{~h}$ significantly decreased, but increased at $144 \mathrm{~h}$, revealing that Myl blockage delayed differentiation of myoblasts. Figure 5B also showed significant delay in myotube formation after Myl1-siRNA treatment. These results demonstrated that Myl, likely Myl1, significantly affected the process of myoblast proliferation by facilitating the differentiation potential of myoblasts.

\section{DISCUSSION}

The present study was designed to test the possible role of Myl in myoblast proliferation. Compared to diaphragmderived myoblasts that displayed a higher expression of Myl combined with a slow proliferation and a rapid fusion into myotubes, EOM-derived myoblasts displayed a lower expression of Myl, combined with a faster proliferation and a delayed fusion into myotubes. Upon blockade of Myl or knockdown of Myl1 in myoblasts, the proliferation rate of myoblasts was enhanced and the myotube formation was delayed. Our results suggested that Myl likely negatively affect the myoblast proliferation by facilitating the terminal differentiation of myoblasts.
$16 \mathrm{~h}$
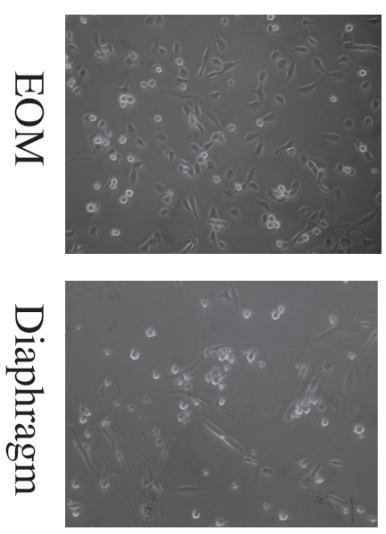

$40 \mathrm{~h}$
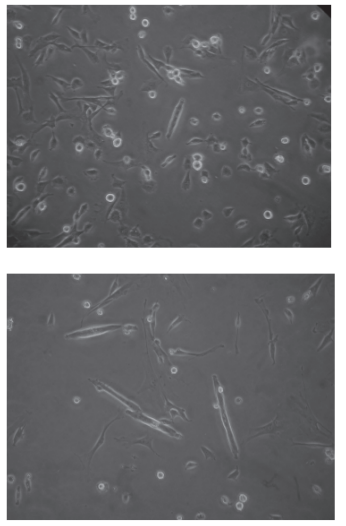

$144 h$
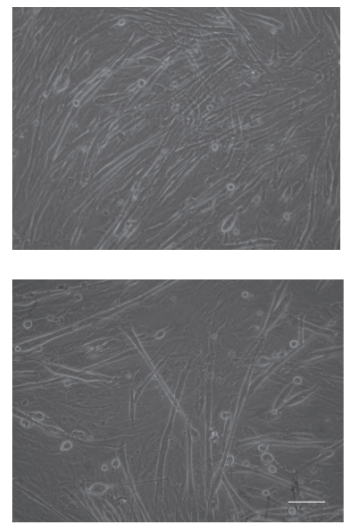

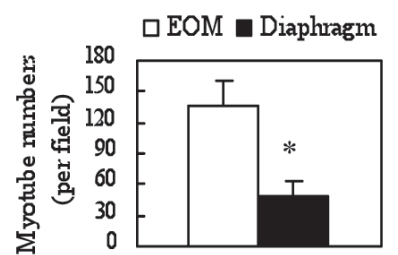

Fig. 4: Myotube formation of different myoblasts. Myoblasts derived from EOM and diaphragm muscles were cultured in growth medium. At $16 \mathrm{~h}$ after seeding, diaphragm-derived myotubes appeared. But EOM derived myoblasts did not form myotubes until another $24 \mathrm{~h}$. At $144 \mathrm{~h}$, myotubes were counted from five random microscopic fields $(200 \times)$ and averaged. The assays were performed in duplicate and means $\pm \mathrm{SD}$ from three independent experiments. ${ }^{*} \mathrm{P}<0.01 \mathrm{vs} \mathrm{EOM}$. Bar, $50 \mu \mathrm{m}$. 
The Myls isoform profile, in developing muscle cells in vivo or in cultured muscle progenitor cells in vitro, has been extensively explored in a variety of species (Keller et al., 1980; Wade et al., 1989; Sutherland et al., 1993; Faerman et al., 1993). It is generally considered that Myls, as well as other muscle specific contractile proteins, are synthesized at the onset of myoblast differentiation. However, different Myl isoforms display a heterogeneous pattern of expression. Myl3 is not expressed during myogenesis in culture and can be detected only in mature skeletal muscles (Wade et al., 1989; CohenHaguenauer et al., 1989), as well as the slow-muscle isoform of Myl2 (Sutherland et al., 1993; Sutherland et al., 1990). Here, our results of undetectable Myl2 and Myl3 mRNA in cultured myoblasts were concurrent with these findings. Myl1 and Myl4 gene expression is induced during myogenesis (Keller et al., 1980; Sutherland et al., 1993). However, some studies showed that in earlier development embryo, Myl4 and Myl1 and fast-muscle Myl2 (Mylpf) are sequentially expressed in undifferentiated myoblasts (Faerman et al., 1993; Lyons et al., 1990). Using comparative protoemic strategies, Tannu et al. (2004) also found that proliferating C2C12 myoblasts express Myl1 protein. These results indicated that Myl1, Mylpf and Myl4 gene expression could be
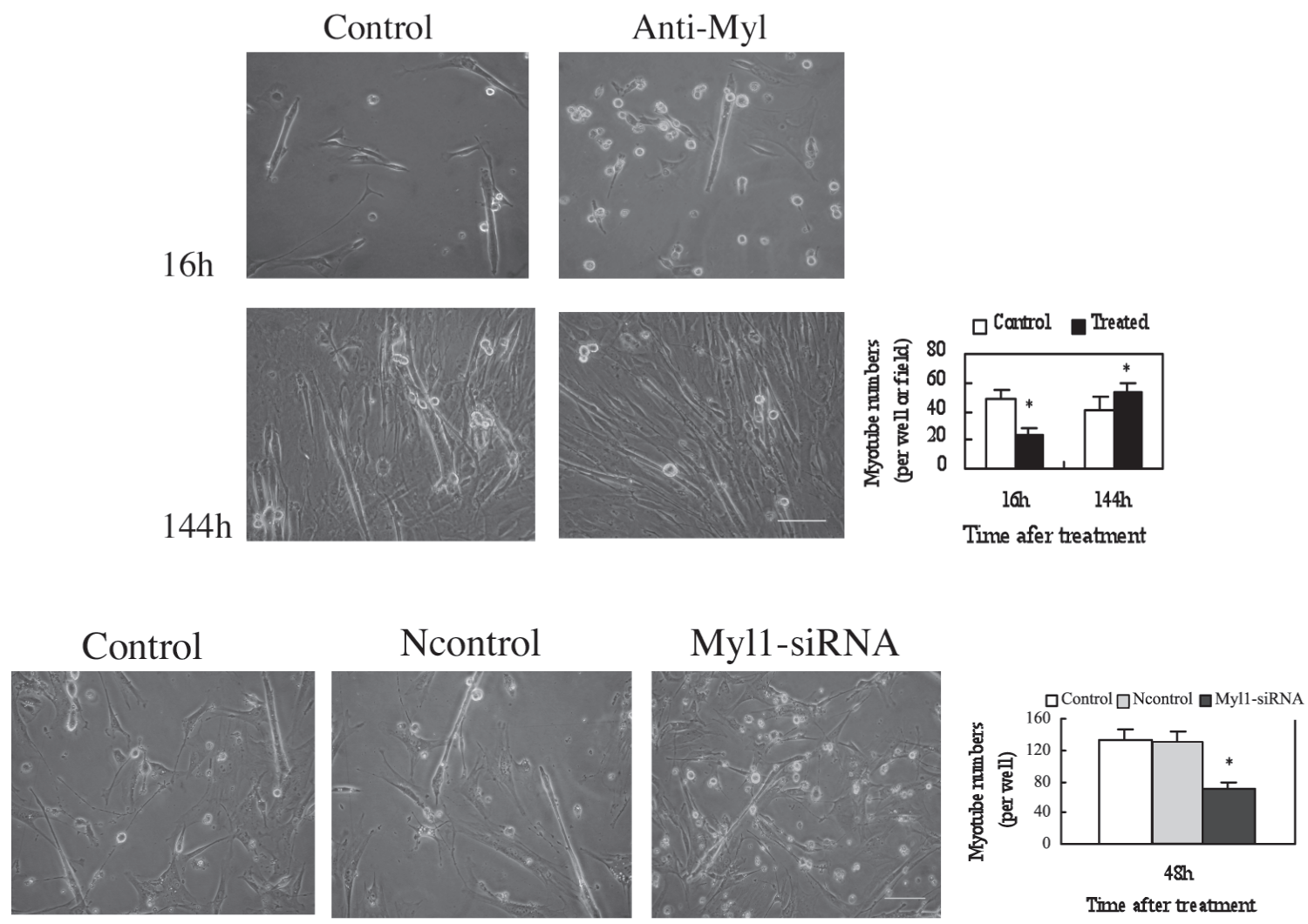

Fig. 5: Effects of Myl blockade and knockdown on differentiation of myoblasts. (A) Diaphragmderived myoblasts were treated with anti-Myl antibody $(8 \mathrm{ng} / \mathrm{ml})$. Afterwards, the number of myotubes per well was quantified at $16 \mathrm{~h}$ or was calculated from five random microscopic fields $(\times 200)$ and averaged at $144 \mathrm{~h}$. The assays were made in triplicate and means \pm SD from three independent experiments. ${ }^{*} \mathrm{P}<0.01$ vs Control. Bar, 50 $\mu \mathrm{m}$. (B) Diaphragm-derived myoblasts cultured overnight $(12 \mathrm{~h})$ were treated with $40 \mathrm{nM}$ Myl1-siRNA. The number of myotubes was counted per well at $48 \mathrm{~h}$ after treatment. The assays were made in triplicate and means \pm SD from three independent experiments. ${ }^{*} \mathrm{P}<0.01$ vs Control and Ncontrol. Bar, 50 $\mu \mathrm{m}$. 
activated before the onset of myogenesis. In our study, at 24h after seeding, Myl1 and Myl4 mRNA in EOM- and diaphragmderived myoblasts were both detected, as well as Myl protein. It suggested that myoblasts could express Myl prior to differentiation, because at this time most myoblasts were in the proliferating state.

We found that EOM-derived myoblasts had a lower level of Myls compared with diaphragm-derived myoblasts. However, the EOM-derived myoblasts proliferated faster than the diaphragm-derived myoblasts, which is consistent with previous studies (McLoon et al., 2002). Studies by Jiang et al. (2002) suggested that precocious expression of MLC $1 \mathrm{f} / 3 \mathrm{f}$ (i.e. Myl1) could disrupt cell proliferation in developmental mouse embryos. According to these results, we therefore proposed that the level of Myl expression could be related to myoblast proliferation. In accordance with the hypothesis, the proliferation of myoblasts was enhanced with the neutralization of Myl by anti-Myl antibody or deletion of Myl1 by RNA interference, suggesting that a low level of Myl in myoblasts likely facilitated the myoblasts proliferation. Thus, Myl, likely Myl1, may play a negative role in myoblast proliferation. There are accumulating data pointing to the effectiveness of protein blockage by a specific antibody (Ma et al., 1991; Sun et al., 2002; Schilling et al., 2003; Tampellini et al., 2007). As an extracellular molecule, antibodies can enter cells in culture through membrane receptor-dependent endocytosis and then exert their function. For example, antibodies to a ribosomal protein have been shown to penetrate cells in culture through binding to the P0 protein on cell surfaces and causing profound inhibition of protein synthesis (Koscec et al, 1997) or apoptosis of cells (Sun et al, 2001). Studies by Schilling et al (2003) reported that endocytosed anti-HBs antibody, which was mediated by FcRnreceptor, inhibited the secretion of $\mathrm{HBV}$ virions, and in particular $\mathrm{HBsAg}$, from HBV infected hepatocyte lines. Recent studies showed that internalized $A \beta$ antibodies decrease levels of intracellular
$\mathrm{A} \beta$ in cultured amyloid precursor protein mutant neurons or primary neurons (Tampellini. et al, 2007). However, the biological mechanisms by which the endocytosed antibody comes in contact with its target antigen remains unclear. In the present study, when the anti-Myl antibody concentration was high, its effect on cell proliferation was lost. This may be due to the cytotoxic effect of the antibody or the antibody preservation solution.

Upon activation, more quiescent myoblasts re-enter the $S$ phase from $\mathrm{G} 0 / \mathrm{G} 1$ to undergo cell cycle progression leading to the increased proliferation rate of myoblasts (McCroskery et al., 2003). Alternatively, the increase of myoblast proliferation may be due to the delayed withdrawal of growing myoblasts from the cell cycle. After withdrawal from the cell cycle, myoblasts differentiate into myotubes. The later the myoblasts withdraw from the cell cycle, the more the myotubes might be formed due to a longer proliferating phase. Our myotube experiments confirmed this prediction. Tannu et al. (2004) found that the proliferating $\mathrm{C} 2 \mathrm{C} 12$ myoblasts had a lower expression level of Myll than their differentiated myotubes. Works by Kislinger et al. (2005) revealed that the expression of Myl1 in differentiating myotubes from $\mathrm{C} 2 \mathrm{C} 12$ myoblasts increased progressively following induction of the differentiation program. In this study, we found that the blockage of Myl with antiMyl antibody or deletion of Myl1 by RNA interference delayed the differentiation of myoblasts. These results suggested that a lower level of Myl may delay the withdrawal of myoblasts from the cell cycle and terminal differentiation, consequently increasing the potential for the myoblast proliferation. It is also noteworthy that the BC3H1 muscle cell line, which lacks MyoD (the member of the myogenic regulatory gene family), does not express Myl1 and also does not form multinucleate myotubes during differentiation (Brennan et al., 1990). Although it was thought that the failure to express MyoD was responsible for the defect in differentiation, it was also concluded that Myllwere potentially functional in $\mathrm{BC} 3 \mathrm{H} 1$ cells. 
Taken together, we propose that Myl, likely Myl1, may negatively affect myoblast proliferation by facilitating the exit of myoblasts from the cell cycle to differentiation. Elucidation of the mechanism in which Myl function in myoblast should shed light on the regulatory events that control satellite cell proliferation during muscle regeneration.

\section{ACKNOWLEDGMENTS}

This work was supported by New Century Excellent Talents in Universsity (NCT-07$575)$ and National Natural Science Foundation of China (No. 30670734).

\section{REFERENCES}

ANDRUCHOV O, ANDRUCHOVA O, WANG Y, GALLER S (2006) Dependence of cross-bridge kinetics on myosin light chain isoforms in rabbit and rat skeletal muscle fibres. J Physiol 571: 231-242

BARTON P J, BUCKINGHAM M E (1985) The myosin alkali light chain proteins and their genes. Biochem $\mathrm{J}$ 231: 249-261

BRENNAN T J, EDMONDSON D G, OLSON E N (1990) Aberrant Regulation of MyoD1 Contributes to the Partially Defective Myogenic Phenotype of BC3H1 Cells. J Cell Biol 110: 929-37

CHEN J, KUBALAK S W, MINAMISAWA S, PRICE R L, BECKER D K, HICKEY R, ROSS J, CHIEN K R (1998) Selective requirement of myosin light chain $2 \mathrm{~V}$ in embryonic heart formation. J Biol Chem 273: 12521256

COHEN-HAGUENAUER O, BARTON P J, VAN CONG $\mathrm{N}$, COHEN A, MASSET $\mathrm{M}$, BUCKINGHAM $\mathrm{M}$, FRÉZAL J (1989) Chromosomal assignment of two myosin alkali light-chain genes encoding the ventricular/slow skeletal muscle isoform and the atrial/ fetal muscle isoform (MYL3, MYL4). Hum Genet 81: 278-82

CONBOY I M, CONBOY M J, SMYTHE G M, RANDO T A (2003) Notch-mediated restoration of regenerative potential to aged muscle. Science 302: 1575-1577

DHAWAN J, RANDO T A (2005) Stem cells in postnatal myogenesis: Molecular mechanisms of satellite cell quiescence, activation and replenishment. Trends Cell Biol 15: 666-673

FAERMAN A, SHANI M (1993) The expression of the regulatory myosin light chain 2 gene during mouse embryogenesis. Development 118: 919-929

FISCHER M D, GOROSPE J R., FELDER E, BOGDANOVICH S, PEDROSA-DOMELLÖF F, AHIMA R S, RUBINSTEIN N A., HOFFMAN E P, KHURANA T S (2002) Expression profiling reveals metabolic and structural components of extraocular muscles. Physiol Genomics 9: 71-84

FISCHER M D, BUDAK M T, BAKAY M, GOROSPE J R, BUDAK D, BAKAY M , GOROSPE J R, KJELLGREN D, PEDROSA-DOMELLÖF F,
HOFFMAN E P, KHURANA TS (2005) Definition of the unique human extraocular muscle allotype by expression profiling. Physiol Genomics 22: 283-291

GHATPANDE S, SHAFIQ S, SIDDIQUI M A (2001) Ventricular Myosin Light Chain-2 Gene Expression in Developing Heart of Chicken Embryos. Biol Res 34: 1-6

HAILSTONES D L, GUNNING P W (1990) Characterization of human myosin light chains 1 sa and $3 \mathrm{~nm}$ : implications for isoform evolution and function. Mol Cell Biol 10: 1095-1104

HOSEIN R E, GAVIN R H. (2007) Myo1 localizes to phagosomes, some of which traffic to the nucleus in a Myo1-dependent manner in Tetrahymena thermophila. Cell Motil Cytoskeleton 64: 926-35

JIANG P, SONG J, GU G, SLONIMSKY E, LI E, ROSENTHAL N (2002) Targeted Deletion of the MLC1f/3f Downstream Enhancer Results in Precocious MLC Expression and Mesoderm Ablation. Dev Biol 243: 281-293

KAMINSKI H J, AL-HAKIM M, LEIGH R J, KATIRJI M B, RUFF R L (1992) Extraocular muscles are spared in advanced Duchenne dystrophy. Ann Neurol 32: 586588

KELLER L R, EMERSON C P (1980) Synthesis of adult myosin light chains by embryonic muscle cultures. Proc Natl Acad Sci USA 77: 1020-1024

KHURANA T S, PRENDERGAST R A, ALAMEDDINE H $S$, TOME F M, FARDEAU M, ARAHATA K, SUGITA H, KUNKEL L M (1995) Absence of extraocular muscle pathology in Duchenne's muscular dystrophy: role for calcium homeostasis in extraocular muscle sparing. J Exp Med 182: 467-475

KISLINGER T, GRAMOLINI A O, PAN Y, RAHMAN K, MACLENNAN D H, EMILI A. (2005) Proteome dynamics during $\mathrm{C} 2 \mathrm{C} 12$ myoblast differentiation. Mol Cell Proteomics 4: 887-901

KNUDSEN K E, ARDEN K C, CAVENEE W K (1998) Multiple G1 regulatory elements control the androgendependent proliferation of prostatic carcinoma cells. J Biol Chem 273: 20213-20222

KOSCEC M, KOREN E, WOLFSON-REICHLIN M, FUGATE R D, TRIEU E, TARGOFF I N, REICHLIN M. (1997). Autoantibodies to ribosomal P proteins penetrate into live hepatocytes and cause cellular dysfunction in culture. J Immunol 159: 2033-2041

LYONS G E, ONTELL M, COX R, SASSOON D, BUCKINGHAM M (1990) The Expression of Myosin Genes in Developing Skeletal Muscle in the Mouse Embryo. J Cell Biol 111: 1465-76

MA J, CHAPMAN G V, CHEN S L, MELICK G, PENNY R, BREIT S N (1991) Antibody penetration of viable human cells. I. Increased penetration of human lymphocytes by anti-RNP IgG. Clin Exp Immunol 84: 83-91

MCCROSKERY S, THOMAS M, MAXWELL L, SHARMA M, KAMBADUR R (2003) Myostatin negatively regulates satellite cell activation and selfrenewal. J Cell Biol 162: 1135-1147

MCLOON L K, WIRTSCHAFTER J D (2002) Continuous myonuclear addition to single extraocular myofibers in uninjured adult rabbits. Muscle Nerve. 2002, 25: 348358

OLIVER M H, HARRISON N K, BISHOP J E, COLE P J, LAURENT G J (1989) A rapid and convenient assay for counting cells cultured in microwell plates: application for assessment of growth factors. J Cell Sci 92: $513-8$

PORTER J D, MERRIAM A P, LEAHY P, GONG B, FEUERMAN J, CHENG G, KHANNA S (2004) 
Temporal gene expression profiling of dystrophindeficient $(\mathrm{mdx})$ mouse diaphragm identifies conserved and muscle group-specific mechanisms in the pathogenesis of muscular dystrophy. Hum Mol Genet 13: $257-269$

QU-PETERSEN Z, DEASY B, JANKOWSKI R, IKEZAWA M, CUMMINS J, PRUCHNIC R, MYTINGER J, CAO B, GATES C, WERNIG A, HUARD J (2002) Identification of a novel population of muscle stem cells in mice: potential for muscle regeneration. J Cell Biol 157: 851-864

QU Z, BALKIR L, VAN DEUTEKOM J C T, ROBBINS P D, PRUCHNIC R, HUARD J (1998) Development of approaches to improve cell survival in myoblast transfer therapy. J Cell Biol 142: 1257-1267

RANDO T A AND BLAU H M (1994) Primary mouse myoblast purification, characterization, and transplantation for cell-mediated gene therapy. J Cell Biol 125: 1275-1287

RUSHFORTH A M, WHITE C C, ANDERSON P (1998) Functions of the Caenorhabditis elegans regulatory myosin light chain genes mlc-1 and mlc-2. Genetics 150: 1067- 1077

SCHILLING R, IJAZ S, DAVIDOFF M, LEE J Y, LOCARNINI S, WILLIAMS R, NAOUMOV N V (2003) Endocytosis of hepatitis B immune globulin into hepatocytes inhibits the secretion of hepatitis B virus surface antigen and virions. J Virol 77: 88828892

SCHULTZ E, JARYSZAK D L (1985) Effects of skeletal muscle regeneration on the proliferation potential of satellite cells. Mech Ageing Dev 30: 63-72

SHI X, GARRY D J (2006) Muscle stem cells in development, regeneration, and disease. Genes Dev 20: 1692-1708

SUN K H, TANG S J, LIN M L, WANG Y S, SUN G H,
LIU W T (2001) Monoclonal antibodies against human ribosomal $\mathrm{P}$ proteins penetrate into living cells and cause apoptosis of Jurkat $\mathrm{T}$ cells in culture. Rheumatology 40: 750-756

SUTHERLAND C J, ELSOM V L, GORDON M L, DUNWOODIE S L, HARDEMAN E C (1991) Coordination of skeletal muscle gene expression occurs late in mammalian development. Dev Biol 146: 167-78

SUTHERLAND C J, ESSER K A, ELSOM V L, GORDON M L, HARDEMAN E C (1993) Identification of a Program of Contractile Protein Gene Expression Initiated Upon Skeletal Muscle Differentiation. Dev Dyn 196: 25-36

TAMPELLINI D, MAGRANÉ J, TAKAHASHI R H, LI F, LIN M T, ALMEIDA G G, GOURAS G K (2007) Internalized antibodies to the $\mathrm{a} \beta$ domain of APP reduce neuronal $\mathrm{a} \beta$ and protect against synaptic alterations. $\mathrm{J}$ Biol Chem 282: 18895-18906

TANNU N S, RAO V K, CHAUDHARY R M GIORGIANNI F, SAEED A E, GAO Y, RAGHOW R (2004) Comparative Proteomes of the Proliferating C2C12 Myoblasts and Fully Differentiated Myotubes Reveal the Complexity of the Skeletal Muscle Differentiation Program. Mol Cell Proteomics 3: 10651082

TIMSON D J (2003) Fine tuning the myosin motor: the role of the essential light chain in striated muscle myosin. Biochimie 85: 639-645

WADE R, FELDMAN D, GUNNING P, KEDES L (1989) Sequence and expression of human myosin alkali light chain isoforms. Mol Cell Biochem 87: 119-36

YANASE K, MADAIO M P (2005) Nuclear localizing anti-DNA antibodies enter cells via caveoli and modulate expression of caveolin and p53. J Autoimmun 24: $145-151$ 